\title{
PENGARUH GELATIN IKAN PATIN (PANGASIUS DJAMBAL) TERHADAP JUMLAH FIBROBLAS PADA LUKA PASCA PENCABUTAN GIGI TIKUS PUTIH (RATTUS NORVEGICUS)
}

Fredy Mardiyantoro ${ }^{\star}$, Fidya $^{\star}$, Dena Savira Andriani ${ }^{*}$

\section{Keywords: \\ Fibroblast, Patin \\ Fish Gelatin, \\ Glutamine, Tooth \\ Extraction}

\section{ABSTRACT}

Background: Gelatin has been used as a hemostatic agent to stop bleeding and it can be absorbed by human body within 6 hours. The patin fish (Pangasius djambal) gelatin has a high amount of amino acid, especially glutamine which has an important role in increasing the proliferation of fibroblast in wounds. The purpose of this study was to determine the effect of patin fish gelatin to the number of fibroblast in wound after tooth extraction.

Method: Rat's tooth extraction is done on the lower left incisive tooth. Thirty white rats were divided into two groups randomly with 3 time series. Control group was the rats without given of patin fish gelatin and treatment group was the rats given $1 \mathrm{cc}$ of patin fish gelatin with pipette. Socket taken for histologically processed by Hematoxylin Eosin staining.

Result: It showed there were significant differences in the number of fibroblasts between groups. The Post Hoc Tukey test result showed there was a significant difference between the control group and the treatment group.

Conclusion: Patin fish gelatin has effect increasing the number of fibroblast in wound after white rat's (Rattus norvegicus) tooth extraction

\section{PENDAHULUAN}

Pencabutan gigi merupakan tindakan yang sering dilakukan dalam bidang kedokteran gigi, baik itu pencabutan seluruh gigi atau akar gigi dari soketnya pada tulang alveolar. Proses pencabutan memiliki beberapa komplikasi yang dapat terjadi, salah satunya adalah perdarahan pasca pencabutan.

Penyembuhan luka terdiri dari fase inflamasi yang diawali dengan hemostasis kemudian berlanjut dengan fase proliferasi, dan fase maturasi. Fibroblas memiliki peran yang sangat penting dalam proses proliferasi, fibroblas mengeluarkan growth factors yang akan membantu proses perbaikan jaringan luka. Fibroblas mensintesis kolagen, retikuler, serabut elastis dan amorphous extracellular substance ${ }^{1}$.

Gelatin mengandung protein dengan berbagai asam amino yang bermanfaat dalam penyembuhan luka, antara lain glutamin berperan dalam proliferasi fibroblas dan sintesis asam nukleat serta glisin berperan sebagai bahan pembentuk kolagen dan pembuluh darah baru $^{2,3}$.

Sumber utama gelatin adalah dari tulang dan kulit sapi serta babi. Oleh karena itu, perlu dikembangkan bahan baku gelatin selain sapi dan babi yang memiliki kandungan protein serta asam amino yang tinggi sehingga dapat mempercepat proses penyembuhan luka, harganya lebih terjangkau, dan memiliki manfaat lebih banyak dibandingkan dengan spons gelatin $^{4}$. Bahan dasar yang memenuhi kriteria tersebut adalah ikan patin, karena kandungan asam amino glutamin dan glisin dalam gelatin ikan patin lebih tinggi dibandingkan total asam amino pada gelatin komersial ${ }^{5,6}$.

Penelitian ini bertujuan untuk mengetahui pengaruh pemberian gelatin ikan patin (Pangasius djambal) terhadap jumlah fibroblas

\footnotetext{
*Departemen Bedah Mulut dan Maksilofasial Fakultas Kedokteran Gigi Universitas Brawijaya Malang Korespondensi: fredymardiyantoro@gmail.com
} 
pada luka pasca pencabutan gigi tikus putih (Rattus norvegicus).

\section{METODE PENELITIAN}

Penelitian ini menggunakan desain penelitian eksperimental murni dengan Post Test Only Randomized Control Group Design secara in-vivo yang dibagi dalam 2 kelompok dengan 3 time series. Sampel yang digunakan dalam penelitian ini adalah 30 ekor tikus putih jantan (Rattus norvegicus) yang berumur 3 bulan dengan berat 200-250 gram yang dibagi menjadi 6 kelompok. Kelompok $\mathrm{K}$ adalah tikus yang tidak diberi gelatin ikan patin (kelompok kontrol) dan di dekaputasi hari ke 3,5,7 sedangkan kelompok $\mathrm{P}$ adalah tikus yang diberi gelatin ikan patin pada soket pasca pencabutan gigi satu kali setelah ekstraksi dan di dekaputasi pada hari ke 3,5,7. Sampel berupa soket pasca pencabutan gigi insisif rahang bawah. Kemudian dilakukan pembuatan preparat dengan pewarnaan hematoksilin eosin (HE) dan dilakukan penghitungan jumlah fibroblas pada setiap sampel dengan 5 lapang pandang.

Penelitian ini dilakukan di Laboratorium Fakultas Teknologi Hasil Pangan, Laboratorium Biokimia Fakultas Kedokteran, dan Laboratorium Patologi Anatomi Fakultas Kedokteran Universitas Brawijaya. Uji kelaikan etik (Ethical Clearance) dilakukan di Fakultas Kedokteran Universitas Brawijaya dengan No. 399A/EC/ KEPK-FKG/12/2017.

Gelatin ikan patin yang akan di aplikasikan didapat dari kulit ikan patin yang dibuat dengan metode ekstraksi asam basa tanpa proses pengeringan, dan sediaan dalam bentuk gel berwarna bening. ${ }^{6}$

Analisa data menggunakan program SPSS versi 23.0. Uji statistik dengan Shapiro-Wilk, dengan nilai terdistribusi normal $(p>0,05)$ dan uji One-way Anova, dengan nilai signifikansi $p>0,05$ tidak bermakna

\section{HASIL PENELITIAN}

Hasil penelitian didapatkan dari scan preparat histologi di foto dengan perbesaran 400x kemudian dilakukan penghitungan dan dibandingkan antara kelompok kontrol dengan kelompok perlakuan pada hari yang sama.

Jumlah perhitungan fibroblas pada luka pasca pencabutan gigi tikus putih (Rattus norvegicus) yang tidak diberi gelatin ikan patin (Pangasius djambal) sebesar 27,96 pada hari ke-3, sedangkan jumlah fibroblas pada luka yang diberi gelatin ikan patin sebesar 75,32 pada hari ke-3.

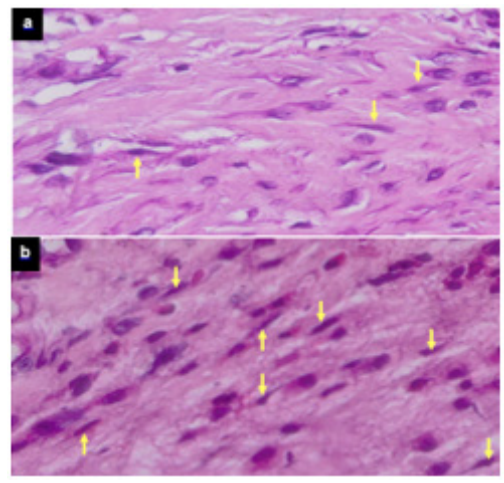

Gambar 1. Gambaran Histologi pada Hari ke-3 a) Kelompok K1, b) Kelompok P1 dalam satu lapang pandang dengan mikroskop cahaya perbesaran $400 x$

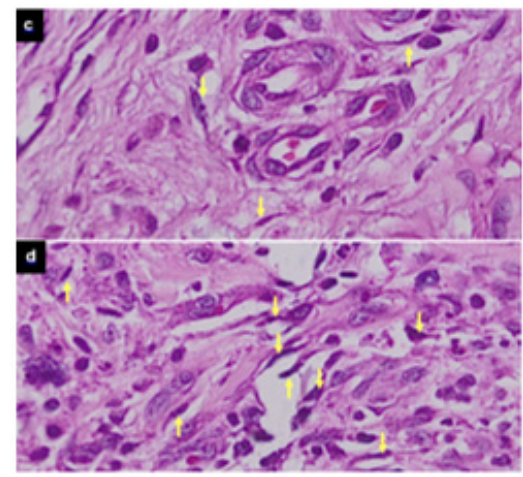

Gambar 2. Gambaran Histologi pada Hari ke-5 a) Kelompok K2, b) Kelompok P2 dalam satu lapang pandang dengan mikroskop cahaya perbesaran $400 x$ 


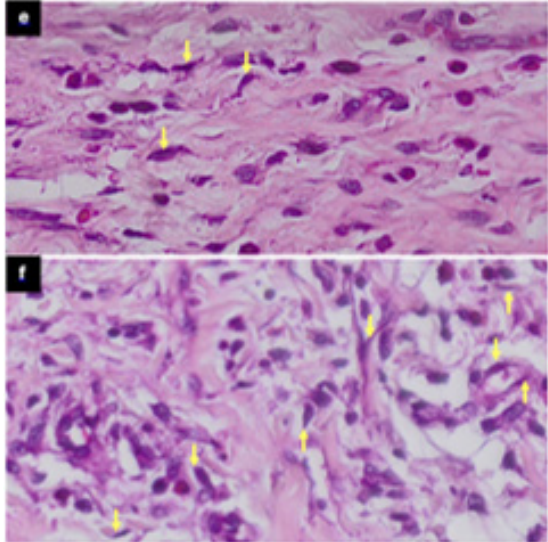

Gambar 3. Gambaran Histologi pada Hari ke-7 a) Kelompok K3, b) Kelompok P3 dalam satu lapang pandang dengan mikroskop cahaya perbesaran $400 x$

Jumlah fibroblas pada luka pasca pencabutan gigi tikus putih (Rattus norvegicus) pada hari ke-5 yang tidak diberi gelatin ikan patin (Pangasius djambal) sebesar 32,04.

Perhitungan jumlah fibroblas pada luka pasca pencabutan gigi tikus putih (Rattus norvegicus) pada hari ke-7 yang tidak diberi gelatin ikan patin (Pangasius djambal) sebesar 36,52, sedangkan jumlah perhitungan fibroblas pada luka pasca pencabutan gigi tikus putih yang diberi gelatin ikan patin sebesar 91,02 . jumlah fibroblas pada luka pasca pencabutan gigi tikus putih pada hari ke-5 yang diberi gelatin sebesar 88,4 . Sedangkan jumlah fibroblas pada luka pasca pencabutan gigi tikus putih pada hari ke-5 yang diberi gelatin sebesar 88,4.

Hasil uji one way Anova didapatkan nilai signifikansi lebih kecil dari 0,05. Maka dapat disimpulkan bahwa $\mathrm{HO}$ ditolak.

Hasil uji Post Hoc Tuckey yang membandingkan antar kelompok dan didapatkan bahwa secara keseluruhan terdapat perbedaan rata-rata jumlah fibroblas yang bermakna antar kelompok dengan nilai signifikansi lebih kecil dari 0,05 , tetapi ada beberapa kelompok yang dibandingkan tetapi nilai signifikansinya lebin besar dari 0,05. Kelompok itu antara lain kelompok $\mathrm{K} 1$ dengan $\mathrm{K} 2$, K1 dengan $\mathrm{K} 3, \mathrm{~K} 2$ dengan $\mathrm{K} 3$, dan $\mathrm{P} 2$ dengan $\mathrm{P} 3$.

\section{DISKUSI}

Penelitian ini mengamati jumlah fibroblas dalam proses penyembuhan luka pencabutan gigi pada tikus putih (Rattus norvegicus). Rata-rata jumlah fibroblas yang terendah pada kelompok kontrol hari ke-3 (K1), sedangkan rata-rata jumlah fibroblas yang tertinggi pada kelompok perlakuan hari ke-7 (P3). Peningkatan jumlah fibroblas menandakan adanya peningkatan proses penyembuhan luka pada soket gigi tikus. Fibroblas mulai bemigrasi ke daerah luka pada hari ke-3 pasca luka, seh-

Tabel 1. Hasil Perhitungan Rata-Rata dan Standar Deviasi Jumlah Fibroblas pada Soket Gigi

\begin{tabular}{lcc}
\hline \multicolumn{1}{c}{ Kelompok } & Mean & Standar Deviasi \\
\hline Kelompok Kontrol Hari ke-3 (K1) & 27,96 & 2,850965 \\
Kelompok Kontrol Hari ke-5 (K2) & 32,04 & 4,043266 \\
Kelompok Kontrol Hari ke-7 (K3) & 36,52 & 5,005197 \\
Kelompok Perlakuan Hari ke-3 (P1) & 75,32 & 6,449186 \\
Kelompok Perlakuan Hari ke-5 (P2) & 88,4 & 4,512206 \\
Kelompok Perlakuan Hari ke-7 (P3) & 91,02 & 6,606966 \\
\hline
\end{tabular}


ingga jumlah fibroblas terendah pada pada hari ke-3. Hal ini didukung oleh penelitian lain oleh Kurnia dkk, yaitu membandingkan jumlah fibroblas pada hari ke-3, hari ke-5 dan hari ke-7 pasca luka pencabutan, hasilnya menunjukkan bahwa fibroblas pada hari ke-3 memiliki jumlah yang terendah, karena pada fase proliferasi fibroblas muncul pada jaringan luka. Jumlah fibroblas akan semakin meningkat dan mencapai puncaknya pada hari ke-7, sehingga jumlah fibroblas pada hari ke-7 memiliki jumlah yang tertinggi. ${ }^{7}$

Hasil pengamatan secara umum menunjukkan perbedaan jumlah fibroblas yang bermakna pada luka pasca pencabutan gigi tikus putih terutama pada kelompok perlakuan yang diberi gelatin ikan patin (Pangasius djambal), jika dibandingkan dengan kelompok kontrol yang tidak diberi gelatin ikan patin pada hari yang sama ( $\mathrm{K} 1$ dengan $\mathrm{P} 1, \mathrm{~K} 2$ dengan $\mathrm{P} 2$, dan K3 dengan P3). Penelitian ini menunjukkan bahwa pemberian gelatin ikan patin (Pangasius djambal) mampu meningkatkan jumlah fibroblas pada luka pasca pencabutan gigi tikus putih.

Gelatin ikan patin mengandung asam amino glisin dan glutamin. Asam amino glutamin berperan dalam meningkatkan proses proliferasi fibroblas sehingga jumlah fibroblas pada jaringan luka akan meningkat, serta menstimulasi pembentukan kolagen sehingga jumlah kolagen akan meningkat. ${ }^{8,9}$

Hal ini menunjukkan bahwa kandungan gelatin ikan patin berperan dalam meningkatkan proses penyembuhan luka melalui peningkatan jumlah fibroblast pada luka.

Kandungan asam amino glisin di dalam gelatin ikan patin memiliki fungsi dalam menstimulasi proses angiogenesis sehinggga terjadi pembentukan pembuluh darah baru yang akan menutrisi jaringan. ${ }^{10}$ Artinya, penyembu- han luka pada tikus yang diberi gelatin ikan patin akan lebih cepat dibandingkan dengan penyembuhan luka pada tikus yang tidak diberi gelatin ikan patin.

Ada beberapa kelompok yang setelah dibandingkan memiliki perbedaan tetapi tidak bermakna. Kelompok tersebut antara lain kelompok K1 dengan K2, K1 dengan K3, K2 dengan K3, dan P2 dengan P3. Kelompok K1 dengan $\mathrm{K} 2$, $\mathrm{K} 1$ dengan $\mathrm{K} 3$ dan $\mathrm{K} 2$ dengan $\mathrm{K} 3$ merupakan perbandingan atara kelompok kontrol. Kelompok tersebut mengalami peningkatan jumlah fibroblas tetapi tidak signifikan. Hal ini disebabkan tanpa pemberian gelatin ikan patin secara fisiologis jumlah fibroblas akan meningkat mulai dari hari ke-3 sampai hari ke7 , tetapi membutuhkan waktu yang lebih lama untuk penyembuhan luka. Hal ini menunjukkan bahwa pemberian gelatin dapat mempercepat proses penyembuhan luka dimana didalam proses penyembuhan luka terdapat proliferasi fibroblas yang meningkat.

Kelompok P2 dengan P3 merupakan perbandingan antara kelompok perlakuan hari ke-5 dengan hari ke-7, kelompok tersebut mengalami peningkatan jumlah fibroblas tetapi tidak memiliki perbedaan yang bermakna. Hal ini disebabkan pemberian gelatin ikan patin akan mengaktivasi fibroblas dan meningkatkan jumlah fibroblas lebih cepat dibandingkan dengan penyembuhan luka tanpa diberi gelatin ikan patin, sehingga pada hari ke-5 fibroblas sudah pada puncaknya dan pada hari ke-7 fibroblas tetap meningkat tetapi tidak dalam jumlah yang signifikan. Penelitian lain yang mendukung yaitu penelitian Meilawaty, bahwa luka yang diberi perlakuan berupa pemberian obat alternatif akan lebih cepat merangsang proliferasi fibroblas sehingga jumlah fibroblas pada daerah luka akan lebih banyak, luka akan cepat menutup dan maturasi sel pada 
luka akan dimulai pada fase remodeling. ${ }^{11}$

Hasil penelitian diatas semakin menguatkan hipotesis penelitian bahwa terdapat pengaruh gelatin ikan patin (Pangasius djambal) terhadap jumlah fibroblas pada luka pasca pencabutan gigi tikus putih (Rattus norvegicus).

\section{KESIMPULAN}

Terdapat pengaruh pemberian gelatin ikan patin (Pangasius djambal) terhadap jumlah fibroblas pada luka pasca pencabutan gigi tikus putih (Rattus norvegicus). Jumlah terendah pada hari ke 3 dan tertinggi pada hari ke 7 pada kelompok kontrol. Sedangkan perbandingan antara kelompok kontrol dan perlakukan memberikan hasil peningkatan jumlah fibroblast lebih banyak pada kelompok perlakuan.

\section{DAFTAR PUSTAKA}

1. Kumar V., Cotran R.S., Robbins S.L. 2015. Buku Ajar Patologi. Edisi 9. Jakarta: Saunders Elsevier.

2. Amstrong D.G., Hanft J.R., Driver V.R., Smith A.P., Lazaro-Martinez J.L., Reyzelman A.M. Research: Treatment Effect of Oral Nutritional Supplementation on Wound Healing in Diabetic Foot Ulcers: a Prospective Randomized Controlled Trial. NCBI. 2014. 31(9).

3. Wang W., Wu Z., Dai Z., Yang Y., Wang J., Wu G. Glycine Metabolism In Animals and Humans: Implications for Nutrition and Health. NCBI. 2013. 45(3).

4. Jannah A. 2008. Gelatin: Tinjauan Kehalalan dan Alternatif Produksinya. Malang: UIN-Malang Press, hal 7-8, 22-26, 70-2.

5. Dewi S. 2011. Jurus Tepat Budidaya Ikan Patin. Yogyakarta: Pustaka Baru Press.

6. Ratnasari I., Yuwono S., Nusyam H., Widjanarko S. Extraction And Characterization Of Gelatin From Different Fresh Water Fishes As Alternative Sources Of Gelatin. International Food Research Journal, 2013, 20(6).
7. Kurnia P.A., Ardhiyanto H.B., Suhartomo. Potensi Ekstrak Teh Hijau (Camellia sinensis) terhadap Peningkatan Jumlah Sel Fibroblas Soket Pasca Pencabutan Gigi pada Tikus Wistar. E-Jurnal Pustaka Kesehatan, 2015, 3(1).

8. Winarno F.G. 2008. Kimia Pangan dan Gizi. Jakarta: PT. Gramedia Pustaka Utama.

9. Ellinger S. Micronutrients, Arginine, and Glutamine: Does Supplementation Provide an Efficient Tool for Prevention and Treatment of Different Kinds of Wounds? Advances in Wound Care. 2015. 3(11).

10. Dewhirst M., Amin K., Li J., Chao W., Haroon Z. Research: Dietary Glycine Inhibits Angiogenesis During Wound Healing and Tumor Growth. Cancer Biology \& Therapy. 2013. 2(2).

11. Meilawaty Z. Uji Ekstrak Getah Biduri (Calotropis gigantea) terhadap Sel Fibroblas Gingiva Tikus Wistar pada Penyembuhan Luka. Prodenta Journal of Dentistry. 2013. 1 (2). 